\title{
126. 弱視者を配慮した街路照明の明るさに関する研究
}

西川 浩代岩田三千子 (摂 南大学)
松井 俊成

（松下電工株式会社）

\section{1.はじめに}

本研究では、本年度報告の「高齢者を配慮した街路 照明の明るさに関する研究、その 1 、その $2 」 と$ 同様 の実験方法によって、弱視者を対象として、対向者の 視認性に関する視認距離と鉛直面照度との関係、およ び街路照明環境に関する雾囲気評価と鈶直面照度との 関係を求めた結果を述べる。

\section{2. 被験者}

被験者は $26 、 31 、 32$ 才の男性 3 名と $22 、 23 、 53$ 才 の女性 3 名の弱視者、計 6 名。

\section{3. 対向者の視認性に関する実験結果}

図 1 に、弱視者の対向者の視認性に関する視認距離 と鈶直面照度との関係を示す。報告その 1 において高 齢者・若年者の視認距離を求めた結果と比較すると、 弱視者は全ての評価において若年者・高龄者より視認 距離が短かかった。

図 2 に、「顔の表情がわかる」のグレア光源無しの場 合を例示する。

\section{4. 雾囲気評価に関する実験結果}

図 3、図 4 に距離 10m、グレア光源有りの場合の「 見やすい・見にくい」、「安心・不安」の評価結果を示す。 「見やすい・見にくい」の評価では、弱視者は若年者、高 齢者より評価が低く、鉛直面照度が高くなると弱視者と 他との評価の差が大きくなった。「明るい・暗い」もこれと 同様の傾向があった。

また、「安心・不安」の評価では、弱視者と他にあまり 差がなかった。「安全・危険」、「快適・不快」、「好き・ 嫌い」もこれと同様の傾向があった。

これより、弱視者は「見やすさ」や「明るさ」などの 物理的要因に基づく評価は低いが、「安心」、「安全」、

「快適」「好み」などの心理的要因に基づく評価は若齢 者・高齢者と差がないことがわかった。

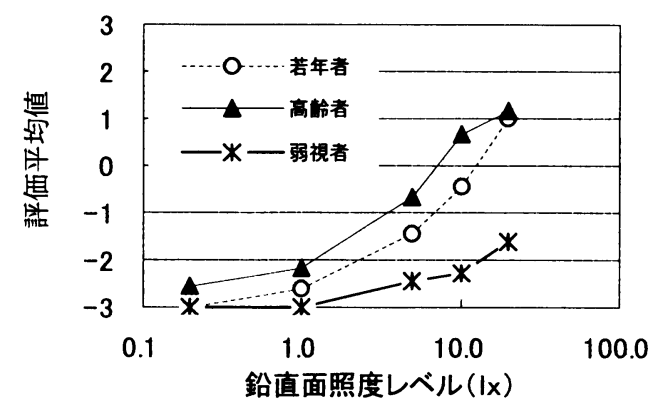

図3「見やすい.見にくい」の評価(10m、グレア光源有り)
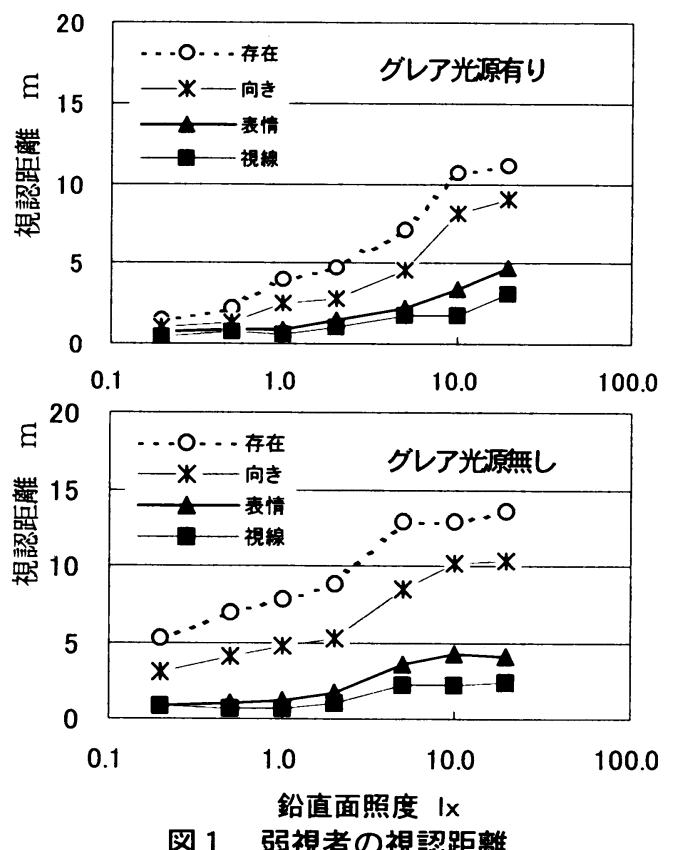

図 1 弱視者の視認距離

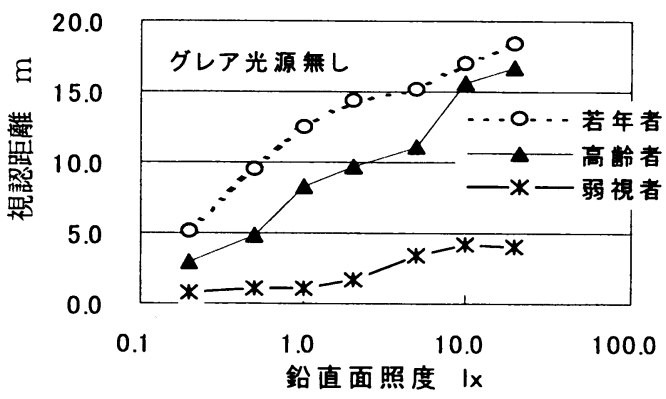

図 2 「顔の表情がかかる」関する視認距離の比較

A study on the Street Lighting considered for low vision Hiroyo NISHIKAWA, Michico IWATA and Toshinari MATSUI 